\title{
Qualitative and Quantitative Changes in Biochemical Constituents in the Rice Plant Treated with Different Xenobiotics
}

\author{
Mangalam Nantha kumar ${ }^{1}$, Vemuri Shashibhushan ${ }^{1}$, Vinnakota Jhansi Lakshmi ${ }^{2}$, Muthugonder Mohan ${ }^{2}$ and \\ Bellamkonda Ramesh ${ }^{1}$ \\ 1. Ainp on Pesticide Residues, Acharya N.G.Ranga Agricultural University, Hyderabad, Andhra Pradesh 500030, India \\ 2. Directorate of Rice Research, Hyderabad, Andhra Pradesh 500030, India
}

Received: April 5, 2012 / Published: January 20, 2013.

\begin{abstract}
Experiments were conducted at Entomology division of Directorate of Rice research to study the qualitative and quantitative changes in biochemical constituents in the rice plant treated with different xenobiotics, viz. insecticides like deltamethrin, imidacloprid, herbicide like 2,4-Dichlorophenoxyacetic acid, fungicide like carbendazim, green manure Calotropis gigantea leaves, botanicals like Neem Seed Powder and fertilizer urea along with control plants of TN1, PTB33 and Swarna varieties comprising of total 15 treatments. Application of butachlor, carbendazim, deltamethrin and excessive nitrogen fertilization resulted in increased population build up of brown plant hopper (BPH). Significantly, lower honeydew excretion (13 $\mathrm{mm}^{2}$ area) in the BPH nymphs was observed on resistant PTB33 variety compared to susceptible TN1 and Swarna varieties (116 and $110 \mathrm{~mm}^{2}$ respectively). In susceptible TN1 variety, the sucrose content was significantly higher ( $9.35 \mathrm{mg} / \mathrm{g}$ tissue) compared to BPH resistant PTB33 (5.32 $\mathrm{mg} / \mathrm{g}$ tissue). The BPH resistant PTB33 variety exhibited significantly lower free amino acid content (1.23 mg/g tissue) as compared to TN1 $(2.51 \mathrm{mg} / \mathrm{g})$. The $\mathrm{C} / \mathrm{N}$ ratio was comparatively high in the resistant PTB33 alone (4.32), but was low in PTB33 applied with 2,4-D + carbendazim (2.73), 2,4-D + imidacloprid + carbendazim (2.3), excess urea fertilizer (2.18). The total phenol contents measured in resistant PTB33 (7.5 mg/g dry wt), susceptible TN1 $(5.865 \mathrm{mg} / \mathrm{g}$ dry wt) and the popular variety Swarna $(5.57 \mathrm{mg} / \mathrm{g} \mathrm{dry}$ wt) were almost same and no statistical difference was observed. Further, treatment of these varieties with different xenobiotics and botanicals also did not significantly alter their total phenol content. However, the phenol content of the resistant PTB 33 alone and treated with xenobiotics was higher compared to the susceptible TN 1 and Swarna varieties alone and treated with xenobiotics. The plant biochemical constituents such as free amino acids, sucrose were lower in untreated resistant PTB33 compared to susceptible TN1, and PTB33 treated with urea and deltamethrin. The high feeding rate and population build up on the susceptible variety TN1 is positively correlated with high quantities of sucrose, free amino acids and lower quantities of phenols and low $\mathrm{C} / \mathrm{N}$ ratio.
\end{abstract}

Key words: 2,4-Dichlorophenoxyacetic acid, Oryza sativa L., xenobiotics, BPH.

\section{Introduction}

Ric Oryza sativa L. is life for more than half of the global population and important food crop all over the world grown in over 154 million hectares with production of 634.5 million tons per annum [1]. India alone produces nearly one fourth $(22 \%)$ of the rice in the world, next to China and stands first in rice area of

Corresponding author: Vemuri Shashibhushan, professor, research fields: specialization, toxicology, pesticide residues and IPM. E-mail: Sash_3156@yahoo.co.in.
44.3 million ha accounting for $28.4 \%$ and second in production of 93.4 MT while China tops in rice production and second in area [2]. The brown plant hopper (BPH), Nilaparvata lugens (Stal.) is one of the most serious insect pests of rice causing significant yield losses [3]. It is more serious in Southern states of Tamil Nadu, Andhra Pradesh, Karnataka and Kerala. In addition to direct damage, it is a vector for Rice Grassy Stunt Virus and Rice Ragged Stunt Virus. Heavy infestations cause complete drying and plant 
death, a condition known as hopper burn. Though the primary methods of control are chemical insecticides and host plant resistance as part of an integrated pest management (IPM), BPH has shown its ability to develop resistance quickly against resistant varieties and insecticides $[4,5]$. BPH is a typical resurgent insect pest and various ecological and cultivation practices trigger higher fecundity, shorter developmental period and increased macropterous production of BPH. All these phenomena lead to population explosion, migration and extensive damage on rice over vast area and even across countries $[6,7]$. Generally, insect resistance to plant allelochemicals might interfere with their resistance to insecticides. Allelochemicals associated with host plant resistance may induce changes in the general detoxification enzymes presumably induced by the plants. Therefore, physiological response of herbivores to host plants may lead to enhanced metabolism of pesticides because mechanisms that function in detoxification of plant allelochemicals in their diets may also be effective at detoxifying pesticides. Hence, a concerted study on the effect of various chemicals such as insecticides, fungicides, botanicals and fertilizers on the plant resistance and BPH hormesis is taken up for their optimal use in rice eco-system to develop a sustainable IPM programme for BPH and also their effects on innate $\mathrm{BPH}$ resistance of three rice varieties, against BPH, were studied.

\section{Materials and Methods}

\subsection{Application of Different Xenobiotics to the Potted Rice Plants}

Experiments were conducted during 2010-2011 at Entomology division of directorate of Rice Research, Hyderabad where is different xenobiotics were used as 20 plants insecticides like deltamethrin, imidacloprid, herbicide like 2,4-D, fungicide like carbendazim, green manure Calotropis gigantea leaves, botanicals like Neem Seed Powder and fertilizer urea along with control plants the varieties of TN1, PTB33 and
Swarna utilizing 20 plants treatment comprising 15 treatments and replicated thrice utilizing 20 plants per treatment. The herbicide 2,4-D (6 mg/pot), green manure Calotropis leaves (50 g/pot), Neem Seed Powder $(2 \mathrm{~g} /$ pot $)$ and Urea $(1 \mathrm{~g} /$ pot $)$ were applied to soil only once at the time of transplanting of rice seedling in the pots. Before transplanting, the xenobiotics were thoroughly mixed with the soil in the pots. The Calotropis leaves were partially decomposed before applying to the pots. The insecticides viz., deltamethrin $(0.5 \mathrm{~mL} / \mathrm{L}$ of water), imidacloprid $(0.5 \mathrm{~mL} / \mathrm{L}$ of water) and the fungicide, carbendazim ( $2 \mathrm{~g} / \mathrm{L}$ of water) were applied by sparying at 30th, 45th and 55th days after transplanting on the potted plants of rice varieties of TN1, PTB33 and Swarna. The 45 days old seedlings of PTB33, TN1 and Swarna varieties were used in the experiment. The pots were thoroughly cleaned and washed with water and kept under shade for drying then were covered with mylar tubes. Twenty three instar BPH nymphs were released on the treated potted plants by using aspirator and the top of the tube was covered with muslin cloth in order to prevent escape of the BPH nymphs and prevent entry of other insects. Observations on percentage mortality of nymphs were recorded at 24, 48, 72, 96 and $120 \mathrm{~h}$ after the release of nymphs.

\subsection{Feeding Experiment}

The seeds of the varieties viz., TN1, PTB33 and Swarna were soaked in plastic petridishes separately and the germinated seeds were sown in $500 \mathrm{~mL}$ plastic pots filled with fertilizer enriched puddled soil. Two germinated seeds were sown in each pot and only one healthy seedling was retained after 10 days. For each entry/variety, seedlings were raised in $8-10$ pots. The plants were used 30 days after sowing for conducting the honeydew experiment.

Nine centimeter diameter circles of whatman number 1 filter paper were prepared. A small hole was made in the center of the circle and a longitudinal cut 
were made in the circle from the margin to the hole. One milligram of bromocresol green powder was added to $1 \mathrm{~L}$ ethyl alcohol solution in a beaker or flask and mixed thoroughly. The solution was taken in a Petri dish and the filter paper circles were dipped in it and dried in shade. The papers were again dipped in the solution to get orange colour. Card board sheet was taken and cut into square shapes of $12 \times 12 \mathrm{~cm}$ size and a hole was made in the center of the square. Wooden planks with a hole in the center can also be used. The stem of the one month old plant was inserted through the hole and the card board square was kept at the base of the plant and the hole was plugged with nonabsorbent cotton. A polythene sheet and a paper were placed on the card board to prevent moisture absorption by the filter paper. The treated filter paper circle were placed on the card board at the base of the plant. A small plastic cup without lid was taken. A small hole was made at the basal portion of the cup and the stem of the plant was inserted through the hole and the cup was placed on the filter paper. The feeding/honeydew test was conducted using both the third instar nymphs and one day old female adults. Five one day old BPH females/3rd instar nymphs (separately for nymphs and adults) were released into the cup onto the filter paper through the hole and the hole were plugged with nonabsorbent cotton to prevent the escape of the insects. The insects were allowed to feed for $24 \mathrm{~h}$ at the base of the stem. The insect has filter chamber mechanism to prevent the entry of excess water present in the plant sap to avoid dilution of digestive enzymes. This excess water were excreted in the form of honeydew droplets. When these droplets came in contact with the filter paper treated with bromocresol green powder, they turned into blue spots. The filter paper was taken out and the area of the spots was measured by graph paper method. The area of all the honeydew spots were traced on a trace paper and the trace paper was kept on a millimeter square graph paper and the number of squares within the spots was counted. The area of all the spots was added and the area of honeydew excretion was expressed as $\mathrm{mm}^{2}$ per five females or five nymphs.

\subsection{Biochemical Analysis of Rice Plant}

All the biochemical components were estimated from whole rice plants collected seven days after second round of treatments. The oven dried samples were analyzed separately in three replications.

\subsubsection{Estimation of Total Phenol}

The total phenol content was estimated following the method of Zieslin and BenZaken [8]. One gram of sample was homogenized in $5 \mathrm{~mL}$ of $85 \%$ ethanol. This homogenized ethanolic extract $(0.5 \mathrm{~mL})$ was added to $2.5 \mathrm{~mL}$ of distilled water and $250 \mu \mathrm{L}$ of Folin-Ciocalteu reagent $(1 \mathrm{~N})$ was added and the solution was kept on a boiling water bath. After $3 \mathrm{~min}$, $0.5 \mathrm{~mL}$ of saturated $\mathrm{Na}_{2} \mathrm{CO}_{3}$ solution and $1 \mathrm{~mL}$ of distilled water were added and the reaction mixture was incubated for $1 \mathrm{~h}$ at $25{ }^{\circ} \mathrm{C}$. The absorbance was measured at $725 \mathrm{~nm}$. Total soluble phenol was calculated according to a standard curve obtained from a Folin-Ciocalteu reagent with catechol $\mathrm{mg} / \mathrm{g}$ dry wt.

\subsubsection{Estimation of Free Amino Acid}

One gram of the sample was ground thoroughly with a pestle and mortar in $0.5 \mathrm{~mL}$ of $80 \%$ ethanol. The homogenate was centrifuged and the supernatant was used for estimation. From the working standard solution containing $100 \mathrm{mg}$ of leucine per milliliter, pipetted out $0.2,0.4,0.6,0.8$ and $1.0 \mathrm{~mL}$ into a series of test tubes and $0.1 \mathrm{~mL}$ of the sample extract. One milliliter of ninhydrin was added and the volume was made upto $2 \mathrm{~mL}$ in all the tubes. The tubes were kept in the boiling water bath for $20 \mathrm{~min}$. Five milliliter of the diluent solvent (equal volume of water and n-propanol) was added, mixed well and allowed to stand for $20 \mathrm{~min}$. The intensity of the purple colour was read at $570 \mathrm{~nm}$. The concentration of total free amino acids in the sample was calculated using the leucine standard curve and expressed as percent equivalent of leucine [9]. 


\subsubsection{Estimation of Sucrose}

The sucrose content in the whole rice plant was measured using the method of Xue [10]. One gram sample was extracted with $3 \mathrm{~mL}$ of $80 \%$ ethanol for 30 min in water bath at $80{ }^{\circ} \mathrm{C}$ and the supernatant was absorbed. The extract was decolorized and filtered by the addition of $100 \mathrm{mg}$ of active carbon. One milliliter of filtered solution was absorbed into a test tube and $0.1 \mathrm{~mL}$ of $2 \mathrm{~N} \mathrm{NaOH}$ was added, kept in boiling water for $10 \mathrm{~min}$ and then cooled. A mixture of $3.5 \mathrm{~mL}$ of $30 \% \mathrm{HCl}$ and $1 \mathrm{~mL}$ of $0.1 \%$ resorcin was added, and kept in bathing water at $80{ }^{\circ} \mathrm{C}$. The mixture was cooled by running water. The absorbance was measured at $480 \mathrm{~nm}$ and the quality of sucrose was expressed terms of $\mathrm{mg} / \mathrm{g}$.

Data on population build up, toxicity, honeydew excretion were subjected to suitable transformation and analysis of variance (ANOVA) was carried out using SAS Version 9.1 [11]. Least square difference (LSD) test was used to compare all the means among treatments to compare the effect of different xenobiotics on BPH growth and development and biochemical parameters at $P \geq 0.05$.

\section{Results and Discussion}

Application of carbendazim, deltamethrin and excessive nitrogen fertilization resulted in increased population build up of BPH Table 1. The present results are in conformity with the findings of Cheng [12], Chelliah and Heinrichs [13], Heinrichs and Medrano [14] who observed that high rate of fertilizer and other chemical inputs such as insecticides

Table 1 Direct toxicity of various xenobiotics to BPH nymphs.

\begin{tabular}{|c|c|c|c|c|c|c|c|}
\hline \multirow[b]{2}{*}{ Tr. No. } & \multirow[b]{2}{*}{ Treatment details } & \multicolumn{5}{|c|}{ Percent mortality of BPH } & \multirow[b]{2}{*}{$\begin{array}{l}\text { Total number of } \\
\text { BPH nymphs/pot }\end{array}$} \\
\hline & & $24 \mathrm{~h}$ & $48 \mathrm{~h}$ & $72 \mathrm{~h}$ & $96 \mathrm{~h}$ & $120 \mathrm{~h}$ & \\
\hline $\mathrm{T} 1$ & PTB 33 (resistant variety) & $\begin{array}{l}5.4^{\mathrm{e}} \\
(13.4)\end{array}$ & $\begin{array}{l}5.4^{\mathrm{e}} \\
(13.4)\end{array}$ & $\begin{array}{l}6.2^{\mathrm{d}} \\
(14.4)\end{array}$ & $\begin{array}{l}6.2^{\mathrm{d}} \\
(14.4)\end{array}$ & $\begin{array}{l}7.5^{\mathrm{e}} \\
(15.7)\end{array}$ & $\begin{array}{l}13.3^{\mathrm{f}} \\
(3.7)\end{array}$ \\
\hline $\mathrm{T} 2$ & TN 1 (susceptible variety) & $\begin{array}{l}0^{\mathrm{f}} \\
(0)\end{array}$ & $\begin{array}{l}0^{f} \\
(0)\end{array}$ & $\begin{array}{l}0^{f} \\
(0)\end{array}$ & $\begin{array}{l}0^{f} \\
(0)\end{array}$ & $\begin{array}{l}0^{\mathrm{f}} \\
(0)\end{array}$ & $\begin{array}{l}244.3^{\mathrm{a}} \\
(15.6)\end{array}$ \\
\hline $\mathrm{T} 3$ & Swarna (popular variety) & $\begin{array}{l}0^{f^{\prime}} \\
(0)\end{array}$ & $\begin{array}{l}0^{f^{\prime}} \\
(0)\end{array}$ & $\begin{array}{l}0^{f^{\prime}} \\
(0)\end{array}$ & $\begin{array}{l}0^{\mathrm{f}^{\prime}} \\
(0)\end{array}$ & $\begin{array}{l}0^{f} \\
(0)\end{array}$ & $\begin{array}{l}191.0^{\mathrm{b}} \\
(13.8)\end{array}$ \\
\hline $\mathrm{T} 4$ & PTB $33+2,4-\mathrm{D}$ & $\begin{array}{l}5.4^{\mathrm{e}} \\
(13.4)\end{array}$ & $\begin{array}{l}5.4^{\mathrm{e}} \\
(13.4)\end{array}$ & $\begin{array}{l}5.8^{\mathrm{d}} \\
(14.0)\end{array}$ & $\begin{array}{l}6.2 \mathrm{~d}^{\mathrm{d}} \\
(14.4)\end{array}$ & $\begin{array}{l}6.2^{\mathrm{e}} \\
(14.4)\end{array}$ & $\begin{array}{l}79.6^{c} \\
(8.9)\end{array}$ \\
\hline T5 & PTB $33+$ carbendazim & $\begin{array}{l}6.2^{\mathrm{de}} \\
(14.4)\end{array}$ & $\begin{array}{l}6.6^{\mathrm{e}} \\
(15.0)\end{array}$ & $\begin{array}{l}9.1^{\mathrm{d}} \\
(17.5)\end{array}$ & $\begin{array}{l}14.1^{\mathrm{d}^{\prime}} \\
(22.0)\end{array}$ & $\begin{array}{l}16.6^{\text {de }} \\
(24.0)\end{array}$ & $\begin{array}{l}35.6^{\mathrm{e}} \\
(5.9)\end{array}$ \\
\hline T6 & PTB $33+2,4-\mathrm{D}+$ carbendazim & $\begin{array}{l}5.4^{\mathrm{e}} \\
(13.4)\end{array}$ & $\begin{array}{l}5.4^{\mathrm{e}} \\
(13.4)\end{array}$ & $\begin{array}{l}5.8^{\mathrm{d}} \\
(14.0)\end{array}$ & $\begin{array}{l}5.8^{\mathrm{d}} \\
(14.0)\end{array}$ & $\begin{array}{l}7.0^{\mathrm{e}} \\
(15.2)\end{array}$ & $\begin{array}{l}51.3^{\mathrm{de}} \\
(7.1)\end{array}$ \\
\hline $\mathrm{T} 7$ & PTB $33+$ deltamethrin & $\begin{array}{l}12.5^{\mathrm{d}} \\
(20.4)\end{array}$ & $\begin{array}{l}15.8^{d} \\
(23.4)\end{array}$ & $\begin{array}{l}34.6^{\mathrm{d}} \\
(35.6)\end{array}$ & $\begin{array}{l}42.5^{\mathrm{c}} \\
(40.6)\end{array}$ & $\begin{array}{l}46.6^{c} \\
(43.0)\end{array}$ & $\begin{array}{l}70.3^{\mathrm{cd}} \\
(8.3)\end{array}$ \\
\hline $\mathrm{T} 8$ & PTB $33+2,4-\mathrm{D}+$ deltamethrin + carbendazim & $\begin{array}{l}58.3^{\mathrm{b}} \\
(50.0)\end{array}$ & $\begin{array}{l}73.3^{\mathrm{b}} \\
(59.3)\end{array}$ & $\begin{array}{l}78.7^{\mathrm{b}} \\
(63.7)\end{array}$ & $\begin{array}{l}79.5^{\mathrm{b}} \\
(64.2)\end{array}$ & $\begin{array}{l}79.5^{\mathrm{b}} \\
(64.2)\end{array}$ & $\begin{array}{l}68.6^{\mathrm{cd}} \\
(8.3)\end{array}$ \\
\hline T9 & PTB 33 + imidacloprid & $\begin{array}{l}87.5^{\mathrm{a}} \\
(70.3)\end{array}$ & $\begin{array}{l}92.5^{\mathrm{a}} \\
(74.2)\end{array}$ & $\begin{array}{l}93.7^{\mathrm{a}} \\
(75.5)\end{array}$ & $\begin{array}{l}93.7^{\mathrm{a}} \\
(75.5)\end{array}$ & $\begin{array}{l}93.7^{\mathrm{a}} \\
(75.5)\end{array}$ & $\begin{array}{l}7.6^{\mathrm{f}} \\
(2.7)\end{array}$ \\
\hline $\mathrm{T} 10$ & PTB 33 + 2,4-D + imidacloprid + carbendazim & $\begin{array}{l}33.3^{\mathrm{c}} \\
(35.0)\end{array}$ & $\begin{array}{l}45.8^{c} \\
(42.5)\end{array}$ & $\begin{array}{l}75.0^{\mathrm{b}} \\
(61.0)\end{array}$ & $\begin{array}{l}85.0^{\mathrm{ab}} \\
(68.7)\end{array}$ & $\begin{array}{l}86.6^{\mathrm{ab}} \\
(69.8)\end{array}$ & $\begin{array}{l}14.0^{f} \\
(3.7)\end{array}$ \\
\hline $\mathrm{T} 11$ & PTB $33+$ Calotropis leaves & $\begin{array}{l}5.8^{\mathrm{e}} \\
(13.9)\end{array}$ & $\begin{array}{l}9.1^{\mathrm{de}} \\
(17.2)\end{array}$ & $\begin{array}{l}9.1^{\mathrm{d}} \\
(17.2)\end{array}$ & $\begin{array}{l}10.0^{\mathrm{d}} \\
(17.9)\end{array}$ & $\begin{array}{l}10.8^{\mathrm{de}} \\
(18.7)\end{array}$ & $\begin{array}{l}15.6^{\mathrm{f}} \\
(3.9)\end{array}$ \\
\hline $\mathrm{T} 12$ & PTB $33+$ neem seed powder & $\begin{array}{l}5.8^{\mathrm{e}} \\
(14.0)\end{array}$ & $\begin{array}{l}6.6^{\mathrm{e}} \\
(14.8)\end{array}$ & $\begin{array}{l}6.6^{\mathrm{d}} \\
(14.8)\end{array}$ & $\begin{array}{l}10.8^{\mathrm{d}} \\
(19.2)\end{array}$ & $\begin{array}{l}10.8^{\text {de }} \\
(19.2)\end{array}$ & $\begin{array}{l}13.6^{\mathrm{f}} \\
(3.7)\end{array}$ \\
\hline $\mathrm{T} 13$ & PTB $33+$ excess urea & $\begin{array}{l}7.0^{\mathrm{de}} \\
(15.2)\end{array}$ & $\begin{array}{l}7.0^{\mathrm{e}} \\
(15.2)\end{array}$ & $\begin{array}{l}7.0^{\mathrm{d}} \\
(15.2)\end{array}$ & $\begin{array}{l}7.5^{\mathrm{d}} \\
(15.8)\end{array}$ & $\begin{array}{l}8.3^{\mathrm{de}} \\
(16.5)\end{array}$ & $\begin{array}{l}48.6^{\mathrm{de}} \\
(7.0)\end{array}$ \\
\hline $\mathrm{T} 14$ & TN $1+$ neem seed powder + Calotropis leaves & $\begin{array}{l}5.8^{\mathrm{e}} \\
(14.0)\end{array}$ & $\begin{array}{l}5.8^{\mathrm{e}} \\
(14.0)\end{array}$ & $\begin{array}{l}7.5^{\mathrm{d}} \\
(15.7)\end{array}$ & $\begin{array}{l}10.8^{d} \\
(19.2)\end{array}$ & $\begin{array}{l}10.8^{\mathrm{de}} \\
(19.2)\end{array}$ & $\begin{array}{l}36.0^{\mathrm{e}} \\
(6.0)\end{array}$ \\
\hline T15 & Swarna + neem seed powder + Calotropis leaves & $\begin{array}{l}7.0^{\mathrm{de}} \\
(15.2)\end{array}$ & $\begin{array}{l}7.5^{\mathrm{e}} \\
(15.5)\end{array}$ & $\begin{array}{l}9.1^{\mathrm{d}} \\
(17.3)\end{array}$ & $\begin{array}{l}10.8^{\mathrm{d}} \\
(19.2)\end{array}$ & $\begin{array}{l}10.8^{\text {de }} \\
(19.2)\end{array}$ & $\begin{array}{l}86.0^{\mathrm{c}} \\
(9.2)\end{array}$ \\
\hline SE & & 2.1 & 2.4 & 2.9 & 2.7 & 2.6 & 0.4 \\
\hline LSD $(0$. & & 6.2 & 7.0 & 8.4 & 8.0 & 7.6 & 1.3 \\
\hline
\end{tabular}

Means followed by the same letters in the same column are not significantly different at $P>0.05$ (LSD, SAS Institute 2006). 
increase reproduction and survival of BPH through favourable alteration of nutritional and other biochemical properties of host plants. Fecundity and survival of BPH was higher in susceptible host plant variety with high rate of nitrogen, phosphorus and potassium fertilizer used $[15,16]$ reported that survival of nymphs and adults, fecundity and egg hatchability were significantly increased by the increase of nitrogen content in host plants which support the present findings.

\subsection{Biochemical Composition of Rice Plants Treated with Different Xenobiotics}

\subsubsection{Changes in Sucrose Content}

The sucrose content in rice plant varied naturally between varieties (Table 2). In susceptible TN1 variety, it was significantly higher $(9.35 \mathrm{mg} / \mathrm{g}$ tissue $)$ compared to BPH resistant PTB33 (5.32 mg/g tissue) and the commercially grown Swarna varieties (7.94 $\mathrm{mg} / \mathrm{g}$ tissue). The PTB 33 recorded the lowest sucrose content $(5.32 \mathrm{mg} / \mathrm{g})$. Treatment of PTB 33 with either imidacloprid spray $(5.90 \mathrm{mg} / \mathrm{g}$ tissue) or Calotrpis leaves $(5.65 \mathrm{mg} / \mathrm{g}$ tissue) or neem seed powder $(5.32$ $\mathrm{mg} / \mathrm{g}$ tissue) as soil amendments also recorded lower sucrose contest and the values were on par with PTB 33 alone. However, treatment of PTB 33 plants with either deltamethrin alone $(9.66 \mathrm{mg} / \mathrm{g}$ tissue) or its combination with 2,4-D and carbendazim $(10.30 \mathrm{mg} / \mathrm{g}$ tissue) significantly increased the plant sucrose content compared to that of susceptible TN1. Application of 2,4-D alone ( $8.36 \mathrm{mg} / \mathrm{g}$ tissue), $2,4-\mathrm{D}+$ carbendazim (7.5 mg/g tissue), 2,4-D + deltamethrin + carbendazim (10.3 mg/g tissue), 2,4-D + carbendazim + imidacloprid ( $6.87 \mathrm{mg} / \mathrm{g}$ tissue) to PTB 33 resulted in the increased amounts of sucrose content in the plant compared to PTB 33 alone (5.32 $\mathrm{mg} / \mathrm{g}$ tissue). Application of neem seed powder + Calotropis leaves as soil amendments decreased the sucrose content to

Table 2 Estimation of rice plants treated with different xenobiotics.

\begin{tabular}{|c|c|c|c|c|c|}
\hline $\begin{array}{l}\text { Tr. } \\
\text { No. }\end{array}$ & Treatment details & $\begin{array}{l}\text { Sucrose } \\
\text { (mg/g dry wt.) }\end{array}$ & $\begin{array}{l}\text { Free amino } \\
\text { (mg/g dry wt.) }\end{array}$ & $\begin{array}{r}\text { acids } \mathrm{C} / \mathrm{N} \\
\text { ratio }\end{array}$ & $\begin{array}{l}\text { Total } \\
\text { phenol Honeydew excretion } \mathrm{mm}^{2} \text { by } \\
\text { (mg/g dry BPH adults } \\
\text { wt.) }\end{array}$ \\
\hline $\mathrm{T} 1$ & PTB 33 (resistant variety) & $5.32 \pm 0.52^{\mathrm{g}}$ & $1.23 \pm 0.12^{\mathrm{cd}}$ & 4.32 & $7.50 \pm 1.1013 .0^{\mathrm{e}}(3.4)$ \\
\hline $\mathrm{T} 2$ & TN 1 (susceptible variety) & $9.35 \pm 1.22^{\mathrm{a}}$ & $2.51 \pm 0.34^{\mathrm{b}}$ & 3.72 & $5.86 \pm 0.98112 .6^{\mathrm{a}}(10.6)$ \\
\hline T3 & Swarna (popular variety) & $7.94 \pm 0.97^{\mathrm{bc}}$ & $1.75 \pm 0.21^{\mathrm{c}}$ & 4.54 & $5.57 \pm 0.79110 .6^{\mathrm{ab}}(10.4)$ \\
\hline $\mathrm{T} 4$ & PTB $33+2,4-\mathrm{D}$ & $8.36 \pm 0.81^{\mathrm{b}}$ & $2.60 \pm 0.09^{\mathrm{b}}$ & 3.22 & $7.06 \pm 1.4533 .6^{\mathrm{cd}}(5.8)$ \\
\hline T5 & PTB $33+$ carbendazim & $6.78 \pm 1.02^{\mathrm{de}}$ & $1.56 \pm 0.13^{\mathrm{cd}}$ & 4.35 & $6.20 \pm 1.1947 .6^{\mathrm{c}}(6.8)$ \\
\hline T6 & PTB $33+2,4-\mathrm{D}+$ carbendazim & $7.50 \pm 1.11^{\mathrm{bcd}}$ & $2.75 \pm 0.89^{\mathrm{b}}$ & 2.73 & $7.57 \pm 1.7574 .3^{\mathrm{abc}}(8.3)$ \\
\hline $\mathrm{T} 7$ & PTB $33+$ deltamethrin & $9.66 \pm 1.45^{\mathrm{a}}$ & $2.53 \pm 0.65^{\mathrm{b}}$ & 3.82 & $6.66 \pm 1.2365 .6 \mathrm{~d}^{\mathrm{bc}}(8.0)$ \\
\hline $\mathrm{T} 8$ & $\begin{array}{l}\text { PTB } 33+2,4-\mathrm{D}+\text { deltamethrin }+ \\
\text { carbendazim }\end{array}$ & $10.30 \pm 2.32^{\mathrm{a}}$ & $2.93 \pm 0.55^{\mathrm{b}}$ & 3.52 & $6.59 \pm 1.5465 .6 \mathrm{~d}^{\mathrm{bc}}(8.1)$ \\
\hline Т9 & PTB 33 + imidacloprid & $5.90 \pm 0.76^{\mathrm{efg}}$ & $1.31 \pm 0.08^{\mathrm{cd}}$ & 4.50 & $6.98 \pm 1.228 .3^{\mathrm{e}}(2.7)$ \\
\hline $\mathrm{T} 10$ & $\begin{array}{l}\text { PTB } 33+2,4-\mathrm{D}+\text { imidacloprid }+ \\
\text { carbendazim }\end{array}$ & $6.87 \pm 1.42^{\text {cde }}$ & $2.98 \pm 0.25^{\mathrm{b}}$ & 2.31 & $6.91 \pm 1.0016 .0^{\mathrm{de}}(4.0)$ \\
\hline T11 & PTB 33 + Calotropis leaves & $5.65 \pm 0.78^{\mathrm{fg}}$ & $1.29 \pm 0.19^{\mathrm{cd}}$ & 4.38 & $7.90 \pm 1.6714 .0^{\mathrm{de}}(3.8)$ \\
\hline $\mathrm{T} 12$ & PTB 33 + neem seed powder & $5.32 \pm 0.89^{\mathrm{g}}$ & $1.35 \pm 0.08^{\mathrm{cd}}$ & 3.94 & $7.65 \pm 1.5910 .6^{\mathrm{e}}(3.3)$ \\
\hline T13 & $\begin{array}{l}\text { PTB } 33+\text { excessive nitrogen } \\
\text { fertilization }\end{array}$ & $6.53 \pm 0.45^{\mathrm{def}}$ & $3.00 \pm 0.20^{\mathrm{a}}$ & 2.18 & $7.21 \pm 1.4647 .0^{c}(6.8)$ \\
\hline T14 & $\begin{array}{l}\mathrm{TN} 1+\text { neem seed powder }+ \\
\text { Calotropis leaves }\end{array}$ & $7.42 \pm 1.11^{\mathrm{bcd}}$ & $1.65 \pm 0.03^{\mathrm{cd}}$ & 4.50 & $5.32 \pm 0.9758 .3^{\mathrm{c}}(7.4)$ \\
\hline \multirow[t]{3}{*}{$\mathrm{T} 15$} & $\begin{array}{l}\text { Swarna }+ \text { neem seed powder }+ \\
\text { Calotropis leaves }\end{array}$ & $6.56 \pm 0.98^{\mathrm{def}}$ & $1.67 \pm 0.06^{\mathrm{cd}}$ & 3.93 & $5.51 \pm 0.5934 .6^{\mathrm{cd}}(5.8)$ \\
\hline & $\mathrm{SE}$ & 0.06 & 0.14 & - & NS \\
\hline & $\operatorname{LSD}(0.05)$ & 0.98 & 0.50 & & 2.4 \\
\hline
\end{tabular}

Means $( \pm \mathrm{SE}$ ) followed by the same letters in a column are not significantly different at $P>0.05$ (LSD, SAS Institute 2006). 
$7.42 \mathrm{mg} / \mathrm{g}$ tissue compared to TN1 alone $(9.35 \mathrm{mg} / \mathrm{g}$ tissue).

3.1.2 Changes in Free Amino Acid Content and $\mathrm{C} / \mathrm{N}$ Ratio

The BPH resistant PTB 33 variety in the present study exhibited significantly lower free amino acid content $(1.23 \mathrm{mg} / \mathrm{g}$ tissue) as compared to TN1 (2.51 $\mathrm{mg} / \mathrm{g})$. The popular commercial variety Swarna (1.75 $\mathrm{mg} / \mathrm{g}$ tissue) also showed free amino acid level at par to that of TN1. The excessive urea application induced the resistant PTB33 plant to release free amino acid in the cell sap (3.0 mg/g tissue). Similarly, application of chemicals like 2,4-D alone $(2.6 \mathrm{mg} / \mathrm{g})$, the xenobiotics in combination with 2,4-D viz., 2,4-D + carbendazim $(2.75 \mathrm{mg} / \mathrm{g}), 2,4-\mathrm{D}+$ deltamethrin + carbendazim (2.93 mg/g), 2,4-D + imidacloprid + carbendazim $(2.98 \mathrm{mg} / \mathrm{g})$ and deltamethrin alone $(2.53 \mathrm{mg} / \mathrm{g})$ on PTB33 resulted in significant increase in free amino acid titer as compared to PTB 33 without any treatment. The free amino acid content in the susceptible TN1 plant got significantly reduced wherever the plants received neem seed powder and Calotropis leaves $(1.65 \mathrm{mg} / \mathrm{g})$ as soil amendments in which the level of free amino acid was compared to that of resistant PTB33 plants. However, there was no change in free amino acid content where ever the resistant PTB33 received neem seed powder and Calotropis leaves as soil amendments.

The higher $\mathrm{C} / \mathrm{N}$ ratio (4.32 for resistant PTB33) was invariably associated with increased fitness of the plant for $\mathrm{BPH}$ attack and decline of $\mathrm{C} / \mathrm{N}$ in rice plant is an important factor that stimulates $\mathrm{BPH}$ feeding. The $\mathrm{C} / \mathrm{N}$ ratio was comparatively high in the resistant PTB 33 alone (4.32), PTB 33 applied with carbendazim (4.35), imidacloprid (4.50), Calotropis leaves (4.38) but was low in PTB 33 applied with 2,4-D (3.22), 2,4-D + carbendazim (2.73), deltamethrin (3.82), 2,4-D + deltamethrin + carbendazim (3.52), 2,4-D + imidacloprid + carbendazim (2.3), excess urea (2.18). In the susceptible $\mathrm{TN} 1$ the $\mathrm{C} / \mathrm{N}$ ratio was low (3.72) and the application of neem seed powder + Calotropis leaves increased the $\mathrm{C} / \mathrm{N}$ ratio (4.5) which was on par with resistant PTB 33. The present results are in confirmation with the earlier results $[17,18]$ who reported less amino acid content in resistant varieties than that in susceptible ones. Suri and Singh [19] reported that there was a positive correlation between increased levels of amino acids in the rice plants and fecundity of $S$. furcifera obviously resulting from improvement in the nutritional quality of the host plant.

\subsubsection{Changes in Phenol Content}

Phenols are known for their feeding deterrent effects against insects. The total phenol content measured in resistant PTB33 (7.5 mg/g dry wt), susceptible TN1 $(5.86 \mathrm{mg} / \mathrm{g}$ dry wt) and the popular variety Swarna (5.57) in the present study was not significantly different. Further, treatment of these varieties with different xenobiotics and botanicals also did not significantly alter their total phenol content. However, the phenol content of the resistant PTB 33 alone and those treated with xenobiotics was higher compared to the susceptible TN1 and Swarna varieties alone and treated with xenobiotics (Table 2). Emanuel et al. [20] reported 1.57 to 1.16 times more phenols in rice genotypes resistant to $S$. furcifera as compared to the susceptible variety $\mathrm{TN} 1$. The present results are in conformity with the above findings. Significantly lower honeydew excretion (13 $\mathrm{mm}^{2}$ area) in the BPH nymphs was observed on resistant PTB33 variety compared to susceptible TN1 and Swarna varieties (116 $\mathrm{mm}^{2}$ and $110 \mathrm{~mm}^{2}$ respectively). There was no increase in honeydew excretion by $\mathrm{BPH}$ where the PTB33 plants were sprayed with imidacloprid (8.3 $\mathrm{mm}^{2}$ ). Excessive honeydew excretion was recorded due to increased feeding by BPH on PTB 33 plants treated with high dose of nitrogenous fertilizer, i.e., urea $\left(47.0 \mathrm{~mm}^{2}\right), 2,4-\mathrm{D}$ plus carbendazim $\left(74.3 \mathrm{~mm}^{2}\right)$, deltamethrin $\left(65.6 \mathrm{~mm}^{2}\right)$. The honeydew excretion in $\mathrm{BPH}$ was reduced significantly in the susceptible plants TN1 and Swarna upon application of soil 
amendments such as neem seed powder + Calotropis leaves (58.3 and $34.6 \mathrm{~mm}^{2}$, respectively) compared to untreated control plants (112.6 and 110.6, Table 3).

The honeydew excretion of BPH adults was significantly less $\left(35.6 \mathrm{~mm}^{2}\right)$ while feeding on the resistant PTB33 plants as compared to 4.8 and 2.8 fold excessive excretion upon feeding on Swarna (244 $\mathrm{mm}^{2}$ ) and TN1 $\left(425.3 \mathrm{~mm}^{2}\right)$ plants. The honeydew excretion in BPH adults was significantly increased due to feeding on PTB 33 plants treated with deltamethrin $\left(376.6 \mathrm{~mm}^{2}\right)$, whereas imidacloprid (19 $\mathrm{mm}^{2}$ ) and soil amendment with neem seed powder $\left(16.3 \mathrm{~mm}^{2}\right)$ recorded significantly lower honeydew excretion. The amount of honeydew excretion on susceptible varieties TN1 and Swarna which received neem seed powder and Calotropis as soil amendments
(132 $\mathrm{mm}^{2}$ and $127.3 \mathrm{~mm}^{2}$, respectively) got reduced significantly over their respective untreated control plants. In susceptible TN 1 variety, the sucrose content was significantly higher $(9.35 \mathrm{mg} / \mathrm{g}$ tissue $)$ compared to BPH resistant PTB33 (5.32 mg/g tissue). Treatment of PTB 33 with either imidacloprid spray (5.9 mg/g tissue) or Calotrpis leaves (5.65 mg/g tissue) or neem seed powder $(5.32 \mathrm{mg} / \mathrm{g}$ tissue) as soil amendments also recorded lower sucrose content whereas treatment of PTB 33 plants with either deltamethrin alone $(9.66 \mathrm{mg} / \mathrm{g}$ tissue $)$ or its combination with 2,4-D and carbendazim $(10.3 \mathrm{mg} / \mathrm{g}$ tissue) significantly increased the plant sucrose content. Application of neem seed powder + Calotropis leaves (T14) as soil amendments decreased the sucrose content to $7.42 \mathrm{mg} / \mathrm{g}$ tissue compared to

Table 3 Toxicity of imidacloprid to the BPH developed on rice varieties that received various xenobiotic applications.

\begin{tabular}{|c|c|c|c|c|c|c|}
\hline \multirow{2}{*}{ Tr. No. } & \multirow{2}{*}{ Treatment details } & \multicolumn{5}{|c|}{ Cumulative percent mortality of BPH } \\
\hline & & $24 \mathrm{~h}$ & $48 \mathrm{~h}$ & $72 \mathrm{~h}$ & $96 \mathrm{~h}$ & $120 \mathrm{~h}$ \\
\hline $\mathrm{T} 1$ & PTB 33 (resistant variety) & $\begin{array}{l}26.6 c \\
(30.2)\end{array}$ & $\begin{array}{l}50.0 \mathrm{~cd} \\
(45.0)\end{array}$ & $\begin{array}{l}50.0 \mathrm{~cd} \\
(45.0)\end{array}$ & $\begin{array}{l}50.0 \mathrm{~cd} \\
(45.0)\end{array}$ & $\begin{array}{l}\text { 60.0cd } \\
(51.1)\end{array}$ \\
\hline $\mathrm{T} 2$ & TN 1 (susceptible variety) & $\begin{array}{l}46.6 \mathrm{bcd} \\
(43.0)\end{array}$ & $\begin{array}{l}50.0 \mathrm{~cd} \\
(45.0)\end{array}$ & $\begin{array}{l}50.0 \mathrm{~cd} \\
(45.0)\end{array}$ & $\begin{array}{l}\text { 60.0bcd } \\
(51.1)\end{array}$ & $\begin{array}{l}70.0 \mathrm{bcd} \\
(57.0)\end{array}$ \\
\hline $\mathrm{T} 3$ & Swarna (popular variety) & $\begin{array}{l}86.6 a \\
(71.6)\end{array}$ & $\begin{array}{l}89.9 \mathrm{a} \\
(74.4)\end{array}$ & $\begin{array}{l}89.9 \mathrm{a} \\
(74.4)\end{array}$ & $\begin{array}{l}93.2 \mathrm{a} \\
(80.0)\end{array}$ & $\begin{array}{l}93.2 \mathrm{a} \\
(80.0)\end{array}$ \\
\hline $\mathrm{T} 4$ & PTB $33+2,4-\mathrm{D}$ & $\begin{array}{l}13.3 \mathrm{e} \\
(17.5)\end{array}$ & $\begin{array}{l}16.6 \mathrm{e} \\
(20.2)\end{array}$ & $\begin{array}{l}16.6 \mathrm{e} \\
(20.2)\end{array}$ & $\begin{array}{l}30.0 \mathrm{~d} \\
(33.3)\end{array}$ & $\begin{array}{l}46.6 \mathrm{~d} \\
(43.0)\end{array}$ \\
\hline $\mathrm{T} 5$ & PTB $33+$ carbendazim & $\begin{array}{l}70.0 \mathrm{abc} \\
(57.7)\end{array}$ & $\begin{array}{l}80.0 \mathrm{abc} \\
(64.6)\end{array}$ & $\begin{array}{l}80.0 \mathrm{abc} \\
(64.6)\end{array}$ & $\begin{array}{l}80.0 \mathrm{abc} \\
(64.6)\end{array}$ & $\begin{array}{l}80.0 \mathrm{abc} \\
(64.6)\end{array}$ \\
\hline T6 & PTB $33+2,4-\mathrm{D}+$ carbendazim & $\begin{array}{l}76.6 \mathrm{ab} \\
(65.5)\end{array}$ & $\begin{array}{l}83.3 \mathrm{ab} \\
(69.4)\end{array}$ & $\begin{array}{l}83.3 \mathrm{ab} \\
(69.4)\end{array}$ & $\begin{array}{l}83.3 \mathrm{ab} \\
(69.4)\end{array}$ & $\begin{array}{l}83.3 \mathrm{abc} \\
(69.4)\end{array}$ \\
\hline $\mathrm{T} 7$ & PTB $33+$ deltamethrin & $\begin{array}{l}13.3 \mathrm{e} \\
(18.0)\end{array}$ & $\begin{array}{l}40.0 \mathrm{de} \\
(39.1)\end{array}$ & $\begin{array}{l}40.0 \mathrm{de} \\
(39.1)\end{array}$ & $\begin{array}{l}43.3 \mathrm{~d} \\
(41.1)\end{array}$ & $\begin{array}{l}63.3 \mathrm{~cd} \\
(53.0)\end{array}$ \\
\hline $\mathrm{T} 8$ & $\begin{array}{l}\text { PTB } 33+2,4-D+\text { deltamethrin } \\
\text { carbendazim }\end{array}$ & $\begin{aligned} & 46.6 \mathrm{bcd} \\
& (42.7)\end{aligned}$ & $\begin{array}{l}60.0 \mathrm{abcd} \\
(51.8)\end{array}$ & $\begin{array}{l}60.0 \mathrm{abcd} \\
(51.8)\end{array}$ & $\begin{array}{l}86.6 \mathrm{a} \\
(75.7)\end{array}$ & $\begin{array}{l}86.6 \mathrm{ab} \\
(75.7)\end{array}$ \\
\hline T9 & PTB $33+$ imidacloprid & - & & & & \\
\hline $\mathrm{T} 10$ & $\begin{array}{l}\text { PTB } 33+2,4-\mathrm{D}+\text { imidacloprid } \\
\text { carbendazim }\end{array}$ & $\begin{aligned} & 36.6 \mathrm{cde} \\
& (36.9)\end{aligned}$ & $\begin{array}{l}56.6 \mathrm{bcd} \\
(48.9)\end{array}$ & $\begin{array}{l}56.6 \mathrm{bcd} \\
(48.9)\end{array}$ & $\begin{array}{l}60.0 \mathrm{bcd} \\
(50.8)\end{array}$ & $\begin{array}{l}60.0 \mathrm{~cd} \\
(50.8)\end{array}$ \\
\hline $\mathrm{T} 11$ & PTB $33+$ Calotropis leaves & $\begin{array}{l}\text { 40.0cde } \\
(38.8)\end{array}$ & $\begin{array}{l}56.6 \mathrm{bcd} \\
(49.2)\end{array}$ & $\begin{array}{l}56.6 \mathrm{bcd} \\
(49.2)\end{array}$ & $\begin{array}{l}60.0 \mathrm{bcd} \\
(51.1)\end{array}$ & $\begin{array}{l}70.0 \mathrm{bcd} \\
(57.0)\end{array}$ \\
\hline $\mathrm{T} 12$ & PTB $33+$ neem seed powder & $\begin{array}{l}36.6 \mathrm{cde} \\
(37.0)\end{array}$ & $\begin{array}{l}43.3 \mathrm{cde} \\
(41.0)\end{array}$ & $\begin{array}{l}43.3 \mathrm{cde} \\
(41.0)\end{array}$ & $\begin{array}{l}50.0 \mathrm{~cd} \\
(45.0)\end{array}$ & $\begin{array}{l}66.6 \mathrm{bcd} \\
(55.0)\end{array}$ \\
\hline $\mathrm{T} 13$ & PTB $33+$ excessive nitrogen fertilization & $\begin{array}{l}36.7 \mathrm{cde} \\
(36.9)\end{array}$ & $\begin{array}{l}66.6 \mathrm{abcd} \\
(59.4)\end{array}$ & $\begin{array}{l}66.6 \mathrm{abcd} \\
(59.4)\end{array}$ & $\begin{array}{l}76.0 \mathrm{abc} \\
(65.2)\end{array}$ & $\begin{array}{l}76.0 \mathrm{abc} \\
(65.2)\end{array}$ \\
\hline T14 & $\begin{array}{l}\mathrm{TN} 1+\text { neem seed powder }+ \text { Calotropis } \\
\text { leaves }\end{array}$ & $\begin{array}{l}\text { is } 66.6 \mathrm{abc} \\
(59.3)\end{array}$ & $\begin{array}{l}73.3 \mathrm{abc} \\
(63.3)\end{array}$ & $\begin{array}{l}73.3 \mathrm{abc} \\
(63.3)\end{array}$ & $\begin{array}{l}83.3 \mathrm{ab} \\
(69.4)\end{array}$ & $\begin{array}{l}83.3 \mathrm{abc} \\
(69.4)\end{array}$ \\
\hline $\mathrm{T} 15$ & $\begin{array}{l}\text { Swarna }+ \text { neem seed powder }+ \text { Calotropis } \\
\text { leaves }\end{array}$ & $\begin{array}{l}\text { is } 56.6 \mathrm{abcd} \\
(49.2)\end{array}$ & $\begin{array}{l}\text { 63.3abcd } \\
(53.0)\end{array}$ & $\begin{array}{l}\text { 63.3abcd } \\
(53.0)\end{array}$ & $\begin{array}{l}80.0 \mathrm{abc} \\
(64.6)\end{array}$ & $\begin{array}{l}80.0 \mathrm{abc} \\
(64.6)\end{array}$ \\
\hline SE & & 7.9 & 8.1 & 8.1 & 7.4 & 7.3 \\
\hline LSD $(0$. & & 23.0 & 23.6 & 23.6 & 21.3 & 21.1 \\
\hline
\end{tabular}

Means followed by the same letters in the same column are not significantly different at $P>0.05$ (LSD, SAS Institute 2006). 
TN1 (T2) alone (9.35 mg/g tissue).

\section{Conclusions}

In the present study, the BPH resistant PTB 33 variety exhibited significantly lower free amino acid content $(1.23 \mathrm{mg} / \mathrm{g}$ tissue) as compared to TN1 (2.51 $\mathrm{mg} / \mathrm{g}$ ). The excessive urea application induced the resistant PTB33 plant to release more free amino acid in the cell sap $(3.0 \mathrm{mg} / \mathrm{g}$ tissue). The free amino acid content in the susceptible TN1 plant got significantly reduced wherever the plants received neem seed powder and Calotropis leaves $(1.65 \mathrm{mg} / \mathrm{g})$ as soil amendments in which the level of free amino acid was compared to that of resistant PTB33 plants. The $\mathrm{C} / \mathrm{N}$ ratio was comparatively high in the resistant PTB33 alone (4.32), but was low in PTB33 applied with 2,4-D + carbendazim (2.73), 2,4-D + imidacloprid + carbendazim (2.3), excess urea fertilizer (2.18). In the susceptible TN1 (T2), the $\mathrm{C} / \mathrm{N}$ ratio was low (3.72) and the application of neem seed powder + Calotropis leaves (T14) increased the $\mathrm{C} / \mathrm{N}$ ratio (4.5) which was on par with resistant PTB33.

The total phenol content measured in resistant PTB33 (7.5), susceptible TN1 (5.86) and the popular variety Swarna (5.57) in the present study were almost same and no statistical difference was observed. Further, treatment of these varieties with different xenobiotics and botanicals also did not significantly alter their total phenol content. However, the phenol content of the resistant PTB33 alone and treated with xenobiotics was higher compared to the susceptible TN1 and Swarna varieties alone and treated with xenobiotics. The population build up and feeding rate of BPH was more in the susceptible TN1 and Swarna, PTB33 treated with 2,4-D and deltamethrin. It was low in untreated PTB33 and PTB33 treated with imidacloprid. The plant biochemical constituents such as free amino acids, sucrose were lower in untreated resistant PTB33 compared to susceptible TN1, and PTB33 treated with urea and deltamethrin. The high feeding rate and population build up on the susceptible variety TN1 is positively correlated with high quantities of sucrose, free amino acids and lower quantities of phenols and low $\mathrm{C} / \mathrm{N}$ ratio.

\section{References}

[1] Food and Agricultural Organization, AGROSTAT: Information system on food and Agriculture, FAO, Rome, 2009.

[2] N. Shobha Rani, G.S.V. Prasad, A.S.R. Prasad, B. Sailaja, P.Muthuraman, S.N. Meera, et al., RICE ALMANAC-INDIA, Directorate of Rice Research Technical Bulletin no. 50, Directorate of Rice Research, Rajendranagar, Hyderabad, Andhra Pradesh, India, 2010.

[3] E.A. Heinrichs, Biology and Management of Rice Insects, Wiley Eastern Ltd. New Delhi, 1994, p. 779.

[4] C.X. Gao, X.H. Gu, Y.W. Bei, Approach of causes on brown planthopper resurgence, Acta Ecologica Sinica 8 (1988) 155-163.

[5] S.N. Alam, M.B. Cohen, Detection and analysis of QTLs for resistance to the brown planthopper, Nilaparvata lugens, in a doubled-haploid rice population, Theoretical and Applied Genetics 97 (1998) 1370-1379.

[6] X.W. Gao, L.N. Peng, D.Y. Liang, Factors causing the outbreak of brown planthopper, Nilaparvata lugens (Stal) in China in 2005, Plant Protection 32 (2006) 23-24.

[7] J.C. Liu, Y. Liao, Analysis of the causes of Nilaparvata lugens outbreak in Anhui province in 2005, China Plant Protection 26 (2006) 34-37.

[8] N. Zieslin, R. Ben-Zaken, Peroxidase activity and presence of phenolic substancesin peduncles of rose flowers, Plant Physiology and Biochemistry 31 (1993) 333-339.

[9] S. Moore, W.H. Stein, Photometric ninhydrin method for use in the chromatography of amino acids, Journal of Biology and Chemistry 176 (1984) 367-388.

[10] Y. Xue, Booklet of Experiments of Plant Physiology, Science and Technology press of Shanghai, Shanghai, P.R. China, 1985, pp. 32-33.

[11] SAS Institute Inc. SAS/STAT_9.1 User'S Guide, SAS Institute Inc, Cary, 2006

[12] C.H. Cheng, Effect of nitrogen application on the susceptibility in rice to brown planthopper attack, Journal of Taiwan Agricultural Research 20 (3) (1971) 21-30.

[13] S. Chelliah, E.A. Heinrichs, Factors affecting insecticide induced resurgence of the brown plant hopper, Nilaparvata lugens on rice, Environmental Entomology 9 (1980) 773-777.

[14] E.A. Heinrichs, F.G. Medrano, Influence of nitrogen fertilizer on the population development of brown planthopper, International Rice, Research Notes 10 (6) 


\section{Qualitative and Quantitative Changes in Biochemical Constituents in the Rice Plant Treated with Different Xenobiotics}

(1985) 20.

[15] P. Visarto, M.P. Zalucki, H.J. Nesbitt, G.C. Jahn, Effect of fertilizer, pesticide treatment, and plant variety on the realized fecundity and survival rates of brown planthopper, Nilaparvata lugens (Stal) (Homoptera: Delphacidae), generating outbreaks in Cambodia, Journal of Asia-Pacific Entomology 4 (1) (2001) 75-84.

[16] Z.X. Lu, X.P. Yu, K.L. Heong, C. Hu, Effect of nitrogen fertilizer on herbivores and its stimulation to major insect pests in rice, Rice Science 14 (1) (2007) 56-66.

[17] Z.Q. Zhang, J.Y. Gu, Nutritional effects of some amino acids in rice plant, Acta Entomologica Sinica 28 (1) (1985) 15-21.
[18] U.K. Nanda, D. Dash, L.K. Rath, Biochemical basis of resistance in rice to brown planthopper, Nilaparvata lugens, Indian Journal of Entomology 62 (3) (2000) 239-241.

[19] K.S. Suri, G. Singh, Insecticide-induced resurgence of the whitebacked planthopper Sogatella furcifera (Horvath) (Hemiptera: Delphacidae) on rice varieties with different levels of resistance, Crop Protection 30 (2011) 118-124.

[20] N. Emanuel, S. Suresh, P. Ashok, Biochemical basis of resistance in rice hybrids and conventional varieties against whitebacked plant hopper, Sogatella furcifera (Horvath), Annals of Plant Protection Science 10 (2) (2002) 212-215. 